\title{
Teenagers' Entertainment Satisfaction in Watching Talk Show Program through Youtube
}

\section{Hiburan yang Memuaskan Remaja ketika Menonton Program Talk Show melalui Youtube}

\author{
Rizca Haqqu' ${ }^{\text {, Sri Hastjarjo', Yulius Slamet }}{ }^{1}$ \\ ${ }^{1}$ Magister of Communication Science, Faculty of Social and Political Science, \\ Universitas Sebelas Maret, Jl. Ir. Sutami No. 36 A, Kentingan Jebres, Surakarta 57126, \\ Central Java, Indonesia \\ *Corresponding author, e-mail: rizcahaqqu@gmail.com
}

\begin{abstract}
This study was conducted based on the results of research from several survey institutions which explained that there was an indication of shifting patterns from old media to the new media. The researchers wanted to know the level of satisfaction of the youth in using the new media among the community with the students of Universitas Sebelas Maret, generation 2015 to 2017. In this study, the researchers used the Uses and Gratification approaches. The researchers also use quantitative analysis and the Slovin formula to calculate samples of respondents from each generation. The frequency distribution analysis technique was used to calculate the frequency of data and then procentaged. The result of this study is that there is a high level of satisfaction where the majority of the respondents feel that they get the satisfaction they want or look for when watching talk show program through Youtube.
\end{abstract}

Keywords: Youth Entertainment, Talk Show Program, Uses and Gratification, Youtube.

\begin{abstract}
Abstrak
Penelitian ini dilakukan berdasarkan hasil riset dari beberapa lembaga survei yang menjelaskan bahwa adanya indikasi pola pergeseran media lama ke media baru. Peneliti ingin mengetahui tingkat kepuasan remaja dalam menggunakan media baru dikalangan masyarakat terutama responden mahasiswa Universitas Sebelas Maret, angkatan 2015 hingga 2017. Dalam penelitian ini, peneliti menggunakan pendekatan Uses and Gratification. Peneliti juga menggunakan jenis analisis kuantitatif dan rumus Slovin untuk menghitung sampel responden dari masing-masing angkatan. Teknik analisis distribusi frekuensi digunakan untuk menghitung frekuensi data, kemudian diprosentasekan. Hasil dari penelitian ini ialah adanya tingkat kepuasan yang cukup tinggi di mana mayoritas responden merasa mendapatkan kepuasan yang diinginkan atau dicari ketika menonton program acara talk show melalui Youtube.
\end{abstract}

Kata Kunci: Hiburan Remaja, Program Talk Show, Uses and Gratification, Youtube.

Copyright (C) 2019 Universitas Semarang. All rights reserved.

\section{Introduction}

It cannot be denied that mass media has big role or contribution to all aspects of modern society's life. It is not surprising if it is mentioned that mass media has become a medium that helps people spread messages (Sumartono, 2016). Cavalcanti, Pinto, Brubaker, \& Dombrowski (Cavalcanti, Pinto, Brubaker, \& Dombrowski, 2017) explain that the notion of mass communication is as a type of communication delivered through mass media and produce a product in the form of communication messages. The message

Article History: Received October 18, 2018; Revised January 13, 2019; Accepted January 26, 2019; Published January 31, 2019 
is spread continuously to the public in a fixed time interval, for example daily, weekly, monthly through a technology which is carried out by the community.

The development of mass communication technology has an important role in people's life in today's modern era. The media audiences or people are society communities that have different social and cultural arrangements. McQuail explained the definition of audience as a collection of listeners, readers, viewers and spectators. Audiences in mass communication can be interpreted as the recipients of numerous and heterogeneous messages.

In a media system, certain different types are found based on different media technologies: print, television, radio, music recording, internet, telecommunication and so on (Simamora, 2016). The electronic media character combines sound and moving images, while print media conveys information through pictures and writing, and the last, character is internet media which is the collaboration of writing, sound, and moving images in one media. Youtube is a product of the development of mass communication technology which is the most popular among the public.

The presence of technological developments now results in changes in the pattern of the use of conventional media to new media (Haqqu, \& Hastjarjo, 2017). The presence of the new media has increasingly eroded the existence of the old media. Based on the results shown by several survey institutions and the results of the study explained that the presence of Youtube as a video sharing site has increased its users from year to year. It is indirectly begins to shift the existence of conventional media, namely television. So that the television industry inevitably has to start following the development of the current era by creating a channel on the youtube portal where the content presented to the audiences is the television programs. The advantage of Youtube is that with a network system that is connected to a computer or gadget, the users will be able to get information and entertainment in all corners of the world easily by just clicking on a button or searching for certain keywords (Vivian, 2008).

Youtube is a site of various video information from around the world developed by Stevechen, Chad Hurley, and Jawed Karim on February 15, 2005. The strength of this application is the ease of the audiences to share videos that they have with the others and vice versa. The ease of sharing videos makes the video contents on Youtube sites very diverse, such as creative videos, vlogs, tutorials, unboxing and television programs, especially talk show programs.

So that it can be explained that Youtube is a company that collects various collections of video contents, short film television episodes, and full version films. The existence of Youtube is an evidence of the rapid development of today's technology. Audiences can access television programs via Youtube and they are free to choose the desired contents.

Many people think that the presence of Youtube makes the pattern of conventional media shifts to internet media. Some researchers think that someone's pattern of watching now switches to the streaming model using a gadget or computer. In this study the researchers will only focus on studying the talk show programs as the research limitation.

Wibowo (2007) outlines the notion of talk show programs that present speakers who argue with each other and express their opinions which are guided by presenters or hosts who act as the moderators to organize the discussion and to provide questions according to the theme of the event being raised. There are two criteria for talk show programs, namely serious disscusions and like entertainment. Serious disscusions are talk

Jurnal The Messenger, Vol. 11, No. 1, January 2019, pp. 38-45 
shows with special discussions on a topic of issues to be raised such as political or social matters. Whereas like entertainment is a talk show that involves celebrities with themes of discussion that are positive, comfortable, and cheerful.

Almost all people from various circles now use Youtube media to access video information, especially the teenagers. The reason someone uses a media is satisfaction that is obtained based on certain motives. So, when the happiness in using the media is followed by the use of the media, then that's where the satisfaction process in using the media.

The active role of the audience in using the media clarifies the position of the uses and gratification theories in this study. Sianipar (Sianipar, 2013) explains that the uses and gratification theories are more specialized on the human approaches in viewing mass media. Thus, the humans have the authority to treat the media. The use of media among the public explains the need for a media. Katz, Gurevitch and Haas (1973) in Severin, W. J., \& Tankard, Jr. (2011) explain the classifications of five needs, namely escapist needs, personal integrative needs, cognitive need, social integrative needs, and affective needs; based on the stated needs is satisfaction that comes from the motive. Satisfaction is an arising effect based on the desired motive, so that from the motive arises the use of media that produces the effect of satisfaction. Speaking of satisfaction in using media, McQuail identified four types of satisfaction, including: information satisfaction, entertainment satisfaction, personal identity satisfaction, and integrity and social interaction satisfaction (Littlejohn, Foss, \& Oetzel, 2017).

Based on the explanation, the researchers want to conduct a study of how the factors that influence the audience in using Youtube as a media to meet the needs with the teenager respondents, namely the Communication Science Students of Universitas Sebelas Maret, because the communication science students are the students who are aware of the existence of media in their daily life. This shows that the communication science study program students always try to improve their academic abilities in accordance with their scientific discipline (Sianipar, 2013). Students who are used as samples are the students of 2015 to 2017 generations who are registered as active students. While satisfaction in using media is used to find out the results of this study. Based on the phenomenon described above, the researchers conduct a study entitled 'Teenagers' Entertainment Satisfaction in Watching Talk Show Program through Youtube.'

\section{Methodology}

In this study the researchers will focus on the variable of entertainment satisfaction, where the occurrence of a satisfaction is caused by the fulfillment of the need for an entertainment, can release fatigue and boredom. In terms of data and analysis, this study uses quantitative methodology where the data in the form of scoring data obtained will be processed using certain analysis to obtain supporting data for the research. Apart from the results of calculating questionnaires, other data such as references of books, journals, students' scientific works, and research results are used as research supporting data. According to Sugiarto, primary data are the data obtained directly from the field, including the data and information needed (Sugiarto, 2003). Questionaire in this study consists of closed questions where the respondents will choose one of the five answers given from each questions.

Based on the title that the researchers has explained, the location of the study held at the Faculty of Social and Political Sciences of the Communication Studies Department of Universitas Sebelas Maret. The research will be conducted by taking a sample of the 
population of S1 Communication Studies Students (Universitas Sebelas Maret) as many as 84 respondents. This sampling is based on the calculation using the Slovin Formula with sampling errors that can be tolerated by $(10 \%)$ of 525 total students. For the data analysis technique used in this study is the frequency distribution. This frequency distribution can be done by calculating the frequency of the data then presented (Bungin, 2005).

The following is the frequency distribution formula:

Notation:

$$
N=\frac{\mathrm{fx}}{\mathrm{N}} \times 100 \%
$$

fx : Individual Frequency

$\mathrm{N} \quad$ : Number of Events

\section{Result and Discussion}

According to Rosengren, Wenner, \& Palmgreen (1985), the uses and gratification research must accept the motive of the use of media in social roles, how media texts shape the motives, the uses, and the consequences of one's own needs for the acceptance or the rejection of a social status.

The uses and gratification approach is used to see the media phenomena among the people who are always changing to adjust the times. Media audiences are motivated by their needs and choose the type of media to satisfy their needs (Littlejohn, Foss, \& Oetzel, 2017).

The classic uses and gratification theory according to Katz, Blumler, Gurevitch, and Greenberg explained that an antecedent consists of psychological factors, environmental variables such as social systems, organizations, and communication structures (Wang, 2014).

The basic concept of the uses and gratification model summarized by Katz, Jay G. Blumler, and Michael Gurevitch is that social psychological factors create a need and give birth to expectations from the mass media or other sources, causing a pattern of media exposure that results in the fulfillment of needs and other consequences (Rakhmat, 2009).

Based on the explanation above, the following is the result of calculating the frequency of distributions which will then be analyzed according to the implications of the available theory.

According to the research that has been conducted on 84 respondents who have watched talk show programs via Youtube, the results of entertainment satisfaction are as follows:

\begin{tabular}{|cc|c|c|c|c|}
\hline & Frequency & Percentage & $\begin{array}{c}\text { Valid } \\
\text { Percentage }\end{array}$ & $\begin{array}{c}\text { Cumulative } \\
\text { Percentage }\end{array}$ \\
\hline Valid & Do not get & 1 & 1,2 & 1,2 & 1,2 \\
& Get less & 4 & 4,8 & 4,8 & 6,0 \\
Simply get & 44 & 52,4 & 52,4 & 58,3 \\
Srongly get & 35 & 41,7 & 41,7 & 100,0 \\
Total & 84 & 100,0 & 100,0 & \\
\hline
\end{tabular}

Jurnal The Messenger, Vol. 11, No. 1, January 2019, pp. 38-45 
Table 1. Do you get entertainment by watching the Talk Show Program on Youtube?

The data above explains that by watching the talk show program on Youtube, 1 respondent felt that he did not get it, 4 respondents answered that they got it less, while 44 respondents simply got it and 35 respondents were very entertained. In other words, the entertainment obtained by the respondents was by watching the talk show program through Youtube media. So, it could be concluded that more than $90 \%$ of the respondents received the entertainment satisfaction from the talk show program watched with a percentage of $52,4 \%$ simply got and $41,7 \%$ strongly got.

\begin{tabular}{|c|c|c|c|c|c|}
\hline & & Frequency & Percentage & $\begin{array}{c}\text { Valid } \\
\text { Percentage }\end{array}$ & $\begin{array}{l}\text { Cumulative } \\
\text { Percentage }\end{array}$ \\
\hline \multirow[t]{5}{*}{ Valid } & Do not get & 2 & 2,4 & 2,4 & 2,4 \\
\hline & Get less & 2 & 2,4 & 2,4 & 4,8 \\
\hline & Simply get & 37 & 44,0 & 44,0 & 48,8 \\
\hline & Strongly get & 43 & 51,2 & 51,2 & 100,0 \\
\hline & Total & 84 & 100,0 & 100,0 & \\
\hline
\end{tabular}

Table 2. Can you eliminate boredom by watching the Talk Show Program on Youtube?

On the question of whether the respondents felt that they could eliminate boredom when watching talk show program on Youtube media, the majority of the respondents felt strongly got it with a percentage of $51,2 \%$ or a total of 43 people. This shows that Youtube media can provide considerable satisfaction in terms of eliminating boredom when watching talk show programs. The ability of Youtube media that is able to present various types of video contents of the respondents' choices make this media much in demand in terms of releasing the boredom of the routine.

\begin{tabular}{|lc|c|c|c|c|}
\hline & Frequency & Percentage & $\begin{array}{c}\text { Valid } \\
\text { Percentage }\end{array}$ & $\begin{array}{c}\text { Cumulative } \\
\text { Percentage }\end{array}$ \\
\hline Valid & Do not get & 9 & 10,7 & 10,7 & 10,7 \\
& Get less & 14 & 16,7 & 16,7 & 27,4 \\
& Simply get & 45 & 53,6 & 53,6 & 81,0 \\
& Strongly get & 16 & 19,0 & 19,0 & 100,0 \\
& 84 & 100,0 & 100,0 & \\
\hline
\end{tabular}

Table 3. Can you get rid of the problems you are experiencing by watching the Talk Show on Youtube?

Based on the question above, it is known that $10,7 \%$ answered that they did not get it, $16,7 \%$ got less, $53,6 \%$ simply got less and $19,0 \%$ answered that they strongly got it. So, the existence of Youtube media is considered to be able to fulfill entertainment satisfaction where with the Youtube media the respondents can get rid of the problems that they are experiencing. This shows the amount of enthusiasm of the respondents in using Youtube media to meet their needs for entertainment.

Based on the results of the above research, it is known that the majority of the respondents mostly chooses get enough and strongly get, while the minority of the 
respondents chooses get less and do not get. This explains that the various talk show shows that were watched by the respondents through Youtube media provide entertainment satisfaction. Of course the satisfaction obtained by the respondents is inseparable from the desired high level of motivation followed by the use of media, so that there is an effect of satisfaction. The results of this study prove the existing theory that uses and gratification explains the existence of members of the audiences who are considered to be actively use the media to fulfill their needs (Rakhmat, 2009).

The five basic assumptions of the uses and gratification theory explained by Littlejohn, Foss, \& Oetzel (2017) that the existence of media audiences are motivated by their needs and choose the type of media to satisfy their needs; and, using the media into five assumptions, namely: (1) Audiences have many choices in the media, they choose what they want to watch, to listen or to see; (2) The audiences are responsible for choosing the media according to their needs and the media is considered as the factor that contributes to meet the needs; (3) Media institutions create media content that is of interest to the viewers; (4) The surrounding environment affects the media they choose to consume; (5) The media only affects certain audiences because the individual chooses to consume media.

If the results of the study were linked to these five assumptions, the respondents in this study were S1 Students of Communication Science of Universitas Sebelas Maret from 2015 to 2017 generations who were free to choose the desired Talk Show Program. The respondents were responsible for choosing the media to meet their needs based on the satisfaction of entertainment obtained. The respondents will only choose certain content created by media institutions only based on their wishes, and the surrounding environment will influence the choice of content on certain media, in this case Youtube for the choice of media types, where the choice of high categories on television media type is represented by the satisfaction of integration and social interaction, whereas on the type of Youtube media the choice of high category is represented by information motives, entertainment motives, and entertainment satisfaction. The latter assumption gives the conclusion that the media only affects certain audiences because from each respondents only consumes media to fulfill their needs, it can be seen from the differences in the categories of the low, medium and high for certain types of media.

Besides that, the presence of Youtube as a new media makes it easy for audiences to be able to reassess the talk show programs that they want to watch without having to wait for the re-broadcast schedule from the television station. Now almost all television stations have provided channels for related programs both live and taping on the Youtube site, in other words the amount of contents presented and the ease of accessing Youtube media makes it very popular among teenagers. This is proven by the frequency of the respondent choices shown in the results of data processing through SPSS.

\section{Conclusion}

Based on the results of the frequency distribution analysis, the amount of enthusiasm to watch the talk show program via Youtube among the teenagers is great. We can see this in the great choices on medium and high categories. S1 Communication Science Students of Universitas Sebelas Maret from 2015 to 2017 generations as the audiences were well aware of the media choices they wanted. The fulfillment of the five uses and gratification basic assumptions described by Littlejohn, Foss, \& Oetzel explains that the respondents are the active audiences in using the media. So, in this study the

Jurnal The Messenger, Vol. 11, No. 1, January 2019, pp. 38-45 
results found are in accordance with the theoretical understanding used. If in some researches conducted by the researchers stated that conventional media is the media in demand by the public, then in this study, the existence of new media such as Youtube has become a new favorite among teenagers where the users are increasing every year.

The results of this study reinforce the previous research conducted by Tai-Li Wang (2014) entitled 'The Usage Behaviors, Motivations and Gratifications of Using UserGenerated Media: The Case Study of Taiwan's YouTube,' where the results of the research explained the higher the involvement of someone using Youtube media, the higher the satisfaction obtained. So, in the research conducted by the researchers where the satisfaction of watching via Youtube media is high, it comes from the pattern of the high usage of media.

The suggestion for the next research is to analyze how the motive role towards satisfaction in which the use of media becomes the controlling variable of the relationship of these two variables more deeply. So that from the research that will be carried out will find out what factors cause the audiences to use the media, with the hope that the results of the existing studies will enrich the research references on media according to the changing of times.

\section{Acknowledgment}

The researchers would like to thank to thesis supervisor Sri Hastjarjo and Yulius Slamet, and also Universitas Sebelas Maret as the campus where the researchers study.

\section{References}

Bungin, B. (2005). Metodologi Penelitian Kuantitatif. Jakarta: Prenada Media.

Cavalcanti, L. H., Pinto, A., Brubaker, J., \& Dombrowski, L. (2017). Media, Meaning, and Context Loss in Ephemeral Communication Platforms: A Qualitative Investigation of Snapchat. CSCW'17 Proceedings of the 2017 ACM Conference on Computer Supported Cooperative Work and Social Computing, 1933-1945.

Haqqu, R., \& Hastjarjo, S. (2017). Television Media Convergence On Digital Media In Netgen Generation. Surabaya.

Katz, E., Gurevitch, M., \& Haas, H. (1973). On the Use of the Mass Media for Important Things. American Sociological Review, 38(2), 164-181.

Littlejohn, S. W., Foss, K. A., \& Oetzel, J. G. (2017). Theories Of Human Communication (7th ed.). Illinois: Waveland Press.

Rakhmat, J. (2009). Metode Penelitian Komunikasi. Bandung: PT. Remaja Rosdakarya.

Rosengren, K. E., Wenner, L. A., \& Palmgreen, P. (1985). Media Gratifications Research. Washington DC: Sage Publications Inc.

Severin, W. J., \& Tankard, Jr, J. W. (2011). Teori Komunikasi, Sejarah, Metode dan Terapan di dalam Media Massa (5th ed.). Jakarta: Kencana Prenada Media Group.

Sianipar, A. P. (2013). Pemanfaatan Youtube di Kalangan Mahasiswa (Studi Penggunaan Youtube di Kalangan Mahasiswa Ilmu Komunikasi Fisip USU Medan Dengan Pendekatan Uses And Gratification. Jurnal Ilmu Komunikasi FLOW, 3(2), 1-10.

Simamora, E. R. (2016). Spasialisasi dan Konglomerasi Media Pada Kelompok Kompas Gramedia. Jurnal The Messenger, 8(2), 100-111.

Sugiarto. (2003). Teknik Sampling. Jakarta: Gramedia.

Sumartono. (2016). Komodifikasi Media dan Budaya Kohe. Jurnal The Messenger, 8(2), $43-51$.

Vivian, J. (2008). Teori Komunikasi Massa. Jakarta: Prenada Media. 
Wang, T. L. (2014). The Usage Behaviors, Motivations and Gratifications of Using UserGenerated Media: The Case Study of Taiwan's YouTube. Advances in Journalism and Communication, 4(2), 137-150.

Wibowo, F. (2007). Kebudayaan Menggugat. Yogyakarta: Pinus Book Publisher. 